\title{
Eksplorasi Keberadaan Tumbuhan Langka Lokal Bali di Kawasan Hutan Danau Buyan-Tamblingan dan Beberapa Desa di Kabupaten Buleleng Bali
}

\author{
Sutomo \\ UPT Balai Konservasi Tumbuhan Kebun Raya Bali, Candikuning Baturiti Bali 82191 \\ Penulis untuk Korespondensi/E-mail: sutomo.uwa@gmail.com
}

\begin{abstract}
Abstrak - Semakin meningkatnya gangguan terhadap kawasan hutan mengakibatkan sebagian jenis tumbuhan menjadi terancam keberadaannya di alam. Kawasan Bedugul-Batukahu-Pancasari pun tak luput dari gangguan ini. Kebun Raya Bali sebagai lembaga konservasi ex-situ bergerak untuk mulai melakukan konservasi terhadap lima jenis tumbuhan langka lokal. Lima target tersebut adalah Majegau (Dysoxylum caulostachyum Miq.), Kaliasem (Eugenia polycephala Miq.), Rijasa (Elaeocarpus grandiflora J. E. Smith.), Kemoning (Murraya paniculata Jacq.), dan Tulak (Schefflera elliptica Harms.). Kegiatan eksplorasi di kawasan hutan Danau Buyan-Tamblingan dan beberapa desa di Kabupaten Buleleng Bali pun dilaksanakan untuk tujuan ini. Eksplorasi dilakukan dengan metode wawancara terbuka dengan penduduk lokal dan dengan metode jelajah untuk mendapatkan jenis tumbuhan yang dtargetkan baik di kawasan hutan maupun kawasan sekitar desa yang dikunjungi. Eksplorasi tumbuhan langka ini berhasil mengkoleksi sebanyak 22 nomor koleksi yang terdiri dari 14 suku, 18 marga dan 18 jenis dengan 3 gendub. Dari keseluruhan jenis yang ditargetkan, semua jenis berhasil didapatkan di dalam kegiatan ini.
\end{abstract}

Abstract - Disturbance to forested lands had caused some plant species to become threatened of its existence in the wild. The Bedugul-Batukahu-Pancasari areas also experiencing various disturbances. Bali Botanical Garden as a conservation institution is conducting efforts to conserve targeted species which are in rare status according to IUCN and national criteria. Five plant species were chosen as targets in this expedition in Bali: Majegau (Dysoxylum caulostachyum Miq.), Kaliasem (Eugenia polycephala Miq.), Rijasa (Elaeocarpus grandiflora J. E. Smith.), Kemoning (Murraya paniculata Jacq.), and Tulak (Schefflera elliptica Harms.). This expedition was done using forest exploration and open interview methods to find the targeted species. All of the targeted species were found. We found and collected 22 plant specimens from 14 species and 8 families of locally useful rare plants.

Keywords - Locally rare plants, Bali, Buleleng, Buyan-Tamblingan, Bali Botanical Garden.

\section{PENDAHULUAN}

$\mathrm{D}$ alam kehidupan sehari-harinya masyarakat Bali tidak bisa lepas dari tumbuhantumbuhan yang digunakan untuk sarana upacara, obat, rumah, pura, kerajinan dan musik tradisional (Nala, 1996). Seiring dengan bertambahnya penduduk, meningkat pula kebutuhan tumbuhan yang digunakan oleh masyarakat dimana diantaranya ada yang sudah langka. Lahan vegetasi di Bali semakin berkurang yaitu terjadi karena berubahnya tegalan, kebun kopi menjadi kebun sayur Adnyana menyebutkan di Desa Candikuning dan Pancasari saja lahan vegetasi sudah berkurang 101,1 Ha. [1].

Meningkatnya gangguan terhadap kawasan hutan tersebut juga meningkatkan resiko penurunan keanekaragaman hayati tumbuhannya terutama jenis-jenis tumbuhan yang secara lokal sudah termasuk langka. Dengan, Kebun Raya Eka Karya Bali-LIPI sebagai salah satu lembaga konservasi ex-situ tumbuhan wajib melakukan upaya konservasi jenis tumbuhan langka dan bermanfaat [2]. Dengan demikian perlu dilakukan kegiatan Ekplorasi dan penelitian keberadaan jenis langka 
lokal di kawasan hutan TWA Buyan-Tamblingan Buleleng.Hasil yang diharapkan adalah penyediaan informasi autekologi dan material hidup untuk perbanyakan tumbuhan langka lokal terpilih sebanyak 5 jenis (Tabel 1):

Tabel 1. Status konservasi jenis tanaman target eksplorasi

\begin{tabular}{clcc}
\hline No & \multicolumn{1}{c}{ Nama daerah } & Nama latin & Status konservasi \\
\hline 1 & Majegau & Dysoxylum caulostachyum Miq. & Genting \\
2 & Kaliasem & Eugenia polycephala Miq. & Jarang \\
3 & Rijasa & Elaeocarpus grandiflora J. E. Smith. & Jarang \\
4 & Kemoning & Murraya paniculata Jacq. & Langka \\
5 & Tulak & Schefflerae llipticaHarms. & Jarang \\
\hline
\end{tabular}

I. Pra eksplorasi

Penentuan jenis tanaman yang akan dicari

Penelitian<smiles>CCC</smiles>

Penentuan lokasi

III.

Ke lapangan mencari Informasi dasar Eksplorasi
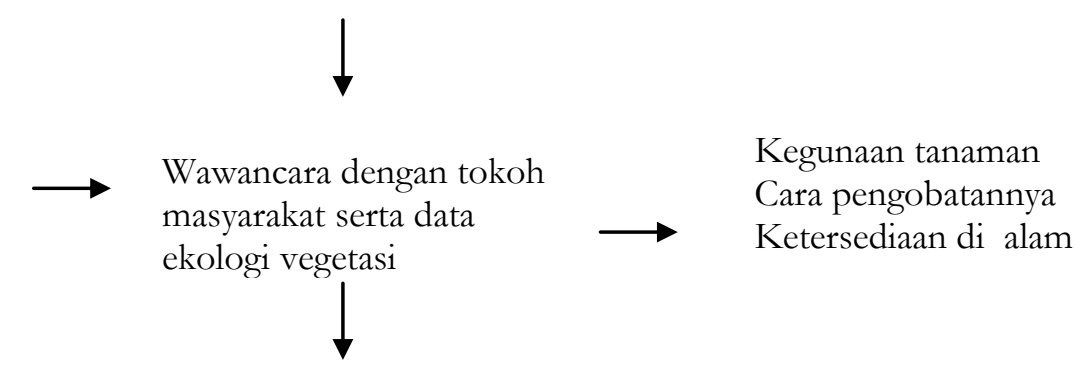

Penelitian

Cara pengobatannya

Cetersedian di alam

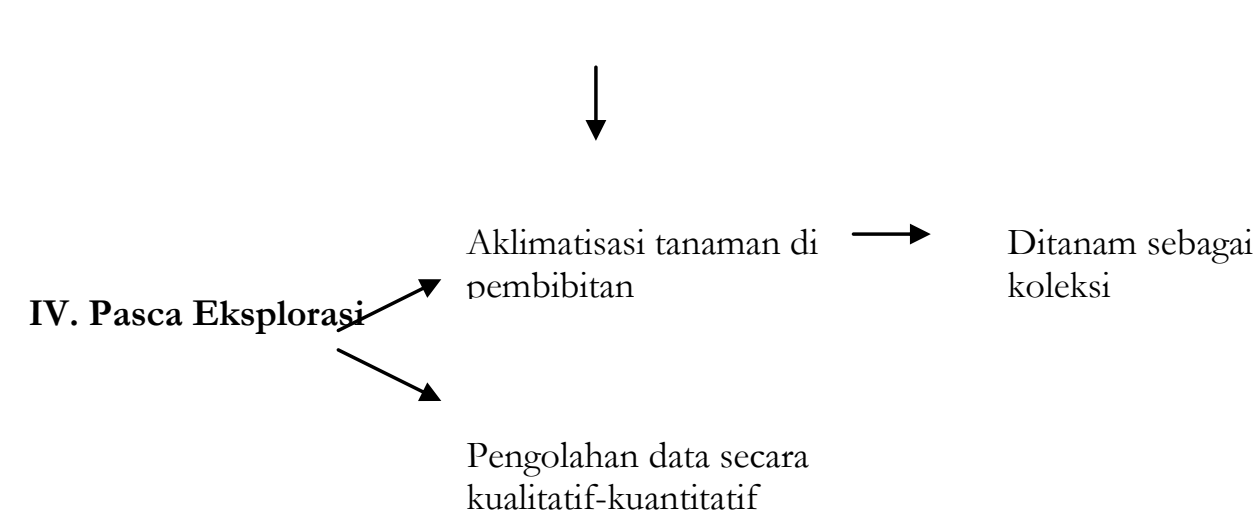

Gambar 1. Bagan alir kegiatan eksplorasi dan penelitian yang dilakukan 


\section{METODE PENELITIAN}

Eksplorasi dan penelitian untuk konservasi tumbuhan obat ini dilaksanakan pada tanggal 2-7 Juni 2010 di Kabupaten Buleleng Bali. Penentuan jenis-jenis prioritas untuk dikoleksi dilakukan dengan berpedoman pada daftar jenis tumbuhan yang dihimpun dari berbagai sumber. Kriteriakriteria untuk jenis-jenis prioritas tersebut meliputi: (1) Jenis-jenis yang memiliki kesesuaian tempat tumbuh, (2) Jenis-jenis yang telah mengalami kelangkaan di alam (3) Jenis-jenis yang banyak digunakan atau bernilai ekonomi dan belum dibudidayakan. Jenis-jenis prioritas tersebut selanjutnya dicari melalui kegiatan eksplorasi dengan menggunakan jasa tokoh masyarakat lainnya sekaligus juga mengumpulkan berbagai keterangan mengenai kegunaan tanaman tersebut di dalam kehidupan sehari-hari (ethnobotany) dengan melakukan wawancara terbuka. Jumlah responden yang diwawancarai juga tidak dibatasi karena kita ingin menggali sebanyak-banyaknya informasi mengenai keberadaan dan manfaat tanaman target. Responden yang utama dijadikan acuan adalah para balian (dukun/pengobat usada), para sesepuh adat dan aparat desa/pemerintahan serta masyarakat umumnya warga desa. Hasil eksplorasi selanjutnya dipersiapkan sebagai koleksi yang akan ditanam dalam satu kawasan kebun setelah melalui prosedur standar dalam protokol koleksi di kebun raya. Secara singkat tahapan dalam kegiatan di lapangan dapat diamati pada diagram (Gambar 1)

\section{KEADAAN UMUM LOKASI}

\section{Kabupaten Buleleng}

Kabupaten Buleleng terletak di belahan Utara Pulau Bali. Memanjang dari Barat ke Timur. Secara geografis Kabupaten Buleleng terletak pada posisi $8^{\circ} 03^{\prime} 40^{\prime \prime}$ Lintang Selatan dan $114^{\circ} 25^{\prime} 55^{\prime}$ " - $115^{\circ} 27^{\prime} 28^{\prime \prime}$ Bujur Timur. Kabupaten Buleleng berbatasan dengan Kabupaten Jembrana di Bagian Barat, Laut Jawa/Bali di Bagian Utara, dengan Kabupaten Karangasem di Bagian Timur dan di Bagian Selatan Berbatasan dengan empat Kabupaten yaitu : Jembrana, Tabanan, Badung dan Bangli. Sebagian besar wilayah di Kabupaten Buleleng merupakan daerah berbukit yang membentang di Bagian Selatan. Kabupaten Buleleng beriklim laut tropis yang dipengaruhi oleh angin musim. Faktor ketinggian tempat menentukan besarnya curah hujan. Luas wilayah Kabupaten Buleleng adalah 136,588 ha atau
24,25\% dari luas propinsi Bali. Hingga tahun 2000 diketahui sebesar 8,46 \% lahan di Kabupaten Buleleng digunakan sebagai lahan sawah, sedangkan $35,64 \%$ nya diperuntukkan sebagai kawasan hutan negara.

\section{Taman Wisata Alam (TWA) Danau Buyan- Tamblingan}

Taman Wisata Alam Danau Buyan-Tamblingan secara geografis terletak pada $8^{\circ} 14$ ' 8 " LS dan $115^{\circ} 05^{\prime} 15^{\prime \prime}$ BT. Berdasarkan data tahun 1997 luas kawasan TWA Buyan-Tamblingan adalah 1.703 ha. Adapun kawasan TWA BuyanTamblingan ini berbatasan dengan Desa Wanagiri, Desa Lemukih di sebelah Utara, hutan lindung, Dusun Peken, Desa Pancasari di sebelah Timur, Desa Batunya, Desa Candikuning disebelah Selatan dan di sebelah Barat berbatasan dengan Dusun Tamblingan, Desa Munduk dan Desa Gesing.

Keadaan topografi kawasan bervariasi dari datar, agak curam sampai sangat curam (Gambar 2) dengan ketinggian antara 1210 - 1350 mdpl. Menurut Klasifikasi iklim oleh Schmidt dan Ferguson, kawasan ini termasuk dalam tipe A dengan rerata curah hujan $2000-2800 \mathrm{~mm} / \mathrm{tahun}$ dan suhu udara berkisar antara $11-25^{\circ} \mathrm{C}$. Sedangkan menurut tipe hutan, kawasan TWA Buyan-Tamblingan ini termasuk tipe hutan hujan tropis pegunungan (dataran tinggi), kondisi kawasan yang selalu basah dan memiliki keanekaragaman yang relatif tinggi (Anonim 2005).

\section{HASIL DAN PEMBAHASAN}

TWA Buyan dan Tamblingan berada pada posisi koordinat $8^{\circ} 15.168^{\prime} \mathrm{S} 115^{\circ} 7.722^{\prime}$ E. Wawancara dengan narasumber polisi hutan TWA BuyanTamblingan terungkap bahwa sebagian besar lahan kritis berada disisi utara danau Buyan dan Tamblingan di daerah Wanagiri dikarenakan adanya penebangan pohon liar di lereng atas oleh masayarakat untuk kemudian dibangun tempat persinggahan wisata yang pemandangannya menghadap ke arah Danau Buyan-Tamblingan. Tahun 2011 telah dilakukan kegiatan reboisasi oleh Kebun Raya Bali dengan bibit Cemara pandak, juga dengan bibit pohon lain seperti Cemara geseng (Casuarina junghuhniana), Cempaka (Michelia campaka), dan Mahoni (Swietenia mahagony). Selain dua tanaman pertama, Mahoni termasuk kategori tanaman 
eksotik yang habitat aslinya bukanlah dari sekitar wilayah Buyan-Tambingan, Bedugul dan sekitarnya.

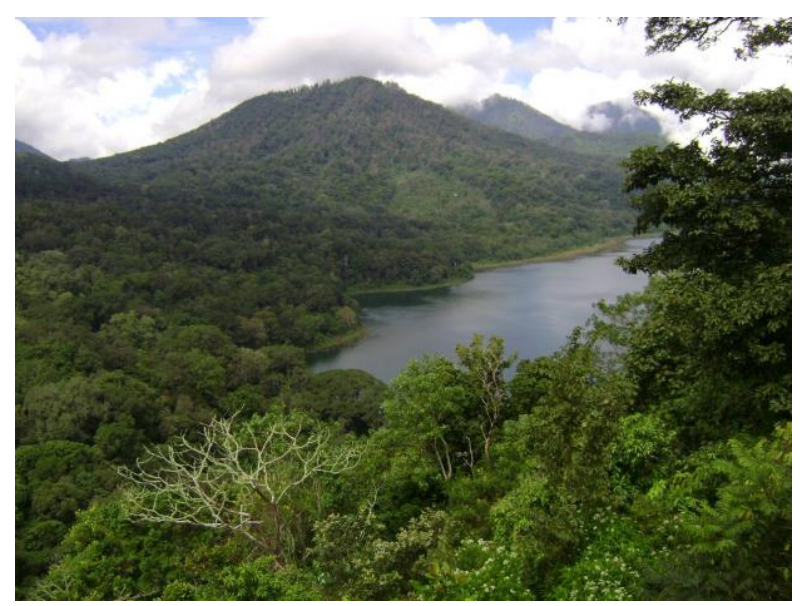

Gambar 2. Areal Taman Wisata Alam Danau BuyanTamblingan

Perjalanan koleksi tanaman dimulai dari daerah depan TWA masuk ke dalam hutan hingga mencapai daerah camping ground di pinggir danau Buyan. Camping ground ini mulai dibuka pada tahun 2001 dengan membabat sebagian lahan hutan dipinggir danau Buyan. Pada saat kunjungan daerah ini ramai dikunjungi oleh turis mancanegara yang sedang berkemah disini. Menurut nara sumber pekerja di camping ground, kualitas air di Buyan dan Tamblingan jauh lebih bagus daripada di Danau Beratan. Air di kedua danau ini masih bisa langsung diminum tanpa harus dimasak terlebih dahulu karena air disini belum terkontaminasi oleh bahan bakar speed boat karena disini tidak diperkenankan adanya moda wisata tersebut, hanya ada perahu nelayan tradisional saja. Danau ini juga sering dipakai untuk mencari ikan oleh para nelayan. Ikan-ikan yang asli di Danau ini adalah Mujair, Karfer, Bandeng, Lele dan Belut (Lindung). Sejak diadakan penaburan benih ikan hias, ikan Sebra, kini hampir sebagian besar ikan di Danau ini dihuni oleh Ikan Sebra (menggeser species asli). Dipinggir-pinggir danau sebelah selatan Buyan ini juga dijumpai beberapa bibit tanaman pohon Mahoni (Swietenia mahagony) yang tumbuh dengan baik. Disini juga penulis dapat mengamati adanya beberapa satwa seperti bangsa aves, burung dari Gianyar nama lokalnya Kokoan.
Penjelajahan kemudian dilanjutkan menuju ke daerah hutan ditengah-tengah antara Danau Buyan dan Tamblingan. Di kawasan ini kami berhasil mendapatkan salah satu dari jenis tanaman yang menjadi target di dalam kegiatan eksplorasi ini yaitu kayu Tulak atau Schefflera elliptica (Tabel 2) ditemukan pada ketinggian $1.150 \mathrm{mdpl}$ dan kelerengan tempat $10^{\circ}$. Tumbuhan ini ditemukan hidup berdekatan dengan pohon Rauvolfia dan Laportea serta Mescereh midtia sebagai tumbuhan bawahnya. Kemudian kami pun berhasil menemukan pohon Majegau Dysoxylum caulostachyum di kawasan ini. Tumbuhan ini hidup bersama dengan pohon Peji (Pinanga sp) dan Cemara Geseng (Casuarina jughuhniana) dan tumbuhan bawah yang teramati adalah jenis Centella asiatica dan beberapa suku Poaceae.

Kegiatan pengamatan data ekologi vegetasi kemudian dilakukan dengan membuat transek arah Utara-Selatan di dalam hutan menembus hutan di daerah hutan Buyan. Plot dibuat berbentuk lingkaran dengan jari-jari $10 \mathrm{~m}$ untuk mengukur pohon (keliling, tinggi, jumlah individu) (Gambar 3) serta lingkaran kecil (jari-jari $2 \mathrm{~m}$ ) di dalam lingkaran besar ini untuk mengamati tumbuhan bawah serta anakan pohon yang diamati jumlah individunya serta jenisnya. Data lingkungan yang diamati dianataranya adalah ketingian tempat, kelerengan, $\mathrm{pH}$ tanah. Di kawasan ini, di sekitar hutan Danau Buyan, kami menyelesaikan sebanyak 20 plot.

Selanjutnya penjelajahan kami lanjutkan ke bagian Utara dari Danau Buyan menuju ke Danau Tamblingan. Dari hasil pengamatan secara singkat di sepanjang tebing hutan di sebelah utara Danau Buyan banyak ditumbuhi oleh pohon Homalanthus, Ficus, Euphorbiaceae, Seming (Ludwigia octovalvis), Podocarpus imbricatus, Michelia campaka, Persea sp, Tunjang langit (Harmsiopanax acuelatus), Bambosa sp, Melastoma, Eupatorium, Paku, Rumput gajah, Solanum, Syzygium dan Sauraria. Sedangkan pada tingkat tumbuhan penutup tanah/tumbuhan bawah (groundcover). Jenis ini memang sering dijumpai ditempat dengan kelerengan yang curam dan menurut Heyne (1987) baik untuk mencegah terjadinya tanah longsor, akan tetapi kehadiran jenis ini juga dapat menjadi indikator kekritisan lahan yang bersangkutan. 


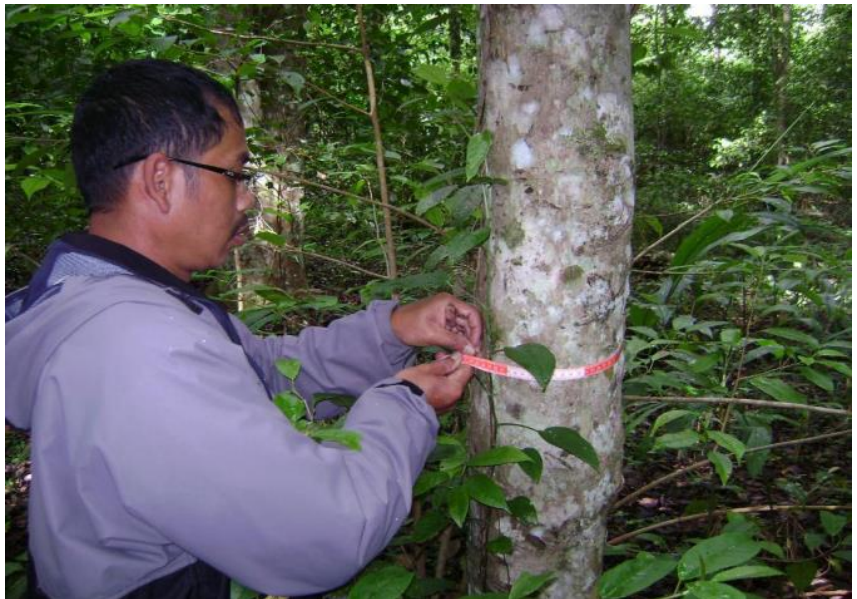

Gambar 3. Mengukur keliling pohon di dalam plot sampel pengamatan di hutan Danau Buyan

Di pinggir barat Danau Tamblingan kami melakukan wawancara dengan penduduk lokal untuk mendapatkan informasi mengenai lokasi dimana ada jenis target (Gambar 4). Berdasarkan wawancara tersebut kami berhasil mendapatkan satu lagi jenis target yaitu Rijasa Elaeocarpus grandiflora. Kemudian kami melakukan pembuatan plot pengamatan vegetasi di sekitar Danau Tamblingan (Gambar 4). Transek dibuat menembus hutan. Tata cara serta bentuk dan ukuran plot serta parameter yang diamati sama dengan pembuatan plot sebelumnya di hutan Danau Buyan. Plot pengamatan dibuat pada tepi hutan alam sampai ke bagian interior hutan dimana dijumpai adanya rumpang akibat pembukaan lahan hutan yang diperuntukkan untuk pura. Hasil dari plot pengamatan struktur dan vegetasi ini nantinya akan diolah untuk mendapatkan data-data ekologi seperti indeks nilai penting, tingkat keanekaragaman jenis di hutan Buyan dan Tamblingan serta analisis kemiripan antara struktur dan komposisi hutan sekitar Danau Buyan dengan hutan di sekitar Danau Tamblingan dengan menggunakan model ordinasi serta cluster analysis. Selain itu data pengamatan juga akan diolah untuk mengetahui pola persebaran dan preferensi jenis sepanjang gradien lingkungan yang diamati. Data-data ini nantinya akan berguna untuk pertimbangan dan perencanan kegiatan reintroduksi tanaman paska penelitian dan pengembangan di dalam kebun.

Dari wawancara dengan kepala dusun Tamblingan didapatkan informasi bahwa beberapa tahun terakhir semenjak 2008 telah sering dilakukan kegiatan reboisasi di kawasan sekitar hutan Danau Tamblingan. Kami pun menjelaskan pula bahwa untuk kegiatan penamaman kembali memang baik akan tetapi akan sangat baik sekali bila yang ditanam adalah jenis-jenis asli atau lokal yang pernah atau masih tersisa tumbuh di sekitar kawasan hutan Danau Tamblingan. Menurut kepala dusun yang kira-kira akan sangat potensial menajdi tanaman reboisasi yang akan digemari oleh penduduk adalah Pohon Sengon (Albizia falcataria) dengan alasan pohon ini cepat tumbuhnya dan dalam waktu 8-10 tahun kayunya sudah bisa dipanen. Selain itu kami pula menambahkan Sengon juga baik untuk memperbaiki kualitas unsur nutrisi tanah karena pohon dari suku Leguminoceae ini juga memiliki kemampuan untuk memfiksasi unsur nitrogen dari udara.

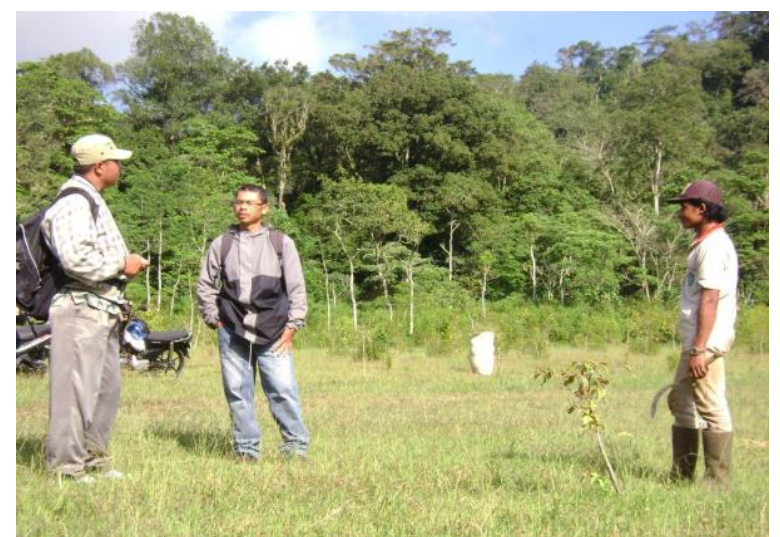

Gambar 4. Kegiatan wawancara dengan penduduk lokal untuk mendapatkan jenis target

Jenis target lainnya yaitu Eugenia polycephala, Murraya paniculata, dan Dysoxylum caulostachyum berdasarkan hasil penjelajahan, pembuatan plot pengamatan serta wawancara kami tidak dapat menjumpai ketiga jenis target lainnya tersebut. Dengan demikian berdasarkan informasi penduduk sekitar juga, kami melanjutkan pencarian sisa tiga jenis target tersebut ke Desa Lemukih dan Desa Sudaji masih di lingkup Kabupaten Buleleng. Perjalanan ke Desa Lemukih melalui perbukitan terjal dan menurun hingga sampai pada ketinggian $600 \mathrm{~m}$ dpl. Disini di Desa Lemukih kami berhasil mendapatkan jenis target yaitu Kaliasem Eugenia polycephala. Jenis ini ditemukan di pinggir kali dengan kelerengan $25^{\circ}$ (Tabel 2) di pinggir jalan desa dan termasuk tempat yang keramat. Selanjutnya di Desa Sudaji pada altitude $320 \mathrm{~m}$ dpl kami pun berhasil mendapatkan Kemoning Murraya paniculata dan sekali lagi, Majegau Dysoxylum caulostachyum (Tabel 2). Gambar 5 menunjukkan grafik perbandingan jumlah koleksi tumbuhan yang ditargetkan di dalam kegiatan eksplorasi ini 
berdasarkan lokasi dimana ditemukannya tumbuhan tersebut.

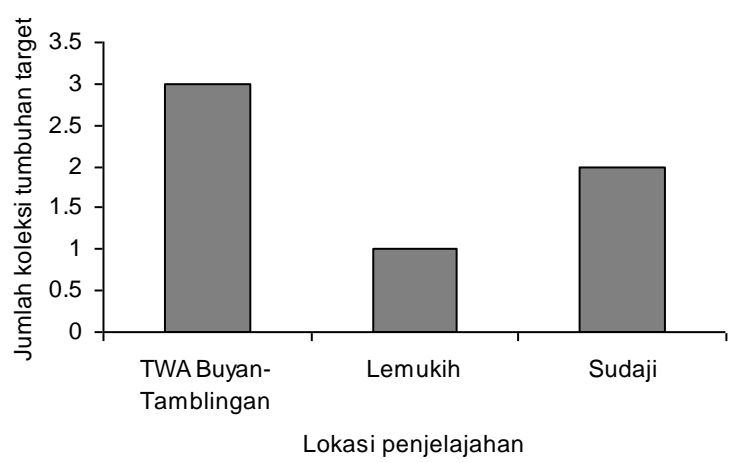

Gambar 5. Lokasi eksplorasi dan jumlah tanaman target yang berhasil dikoleksi

Dengan demikian kegiatan ekspedisi ini cukup sukses yang ditunjukkan dengan terkoleksinya keseluruhan jenis tumbuhan yang ditargetkan. Eksplorasi tumbuhan langka ini berhasil mengkoleksi sebanyak 22 nomor koleksi yang terdiri dari 14 suku, 18 marga dan 18 jenis dengan 3 gendub (Tabel 2). Selain berupa anakan, tim juga mengkoleksi material berupa stek. Ada beberapa tanaman yang diragukan antara nama ilmiah dengan nama lokal yang digunakan dikarenakan keterbatasan pengetahuan kami dalam identifikasi tanaman. Voucher specimen dari lapangan dikoleksi untuk kemudian akan dilakukan identifikasi jenisnya oleh taksonomis di herbarium kebun. Beberapa tanaman perlu untuk dideterminasi ulang sehingga identitas tanaman menjadi lengkap. Setiap koleksi dicari lima spesimen untuk mencegah angka kematian tanaman yang tinggi sebelum ditanam

\section{KESIMPULAN DAN SARAN}

Tim eksplorasi tumbuhan langka Bali di Kabupaten Buleleng memperoleh keseluruhan 5 jenis tumbuhan yang ditargetkan. Eksplorasi tumbuhan langka ini berhasil mengkoleksi sebanyak 22 nomor koleksi yang terdiri dari 14 suku, 18 marga dan 18 jenis dengan 3 gendub. Penelitian autekologi yang dilaksanakan bersamaan dengan kegiatan ini juga akan mendapatkan data yang nantinya akan bermanfaat bagi perencanaan kegiatan reintroduksi tumbuhan. Perlu digiatkan kesadaran akan dampak dari kegiatan manusia dan perubahan iklim global terhadap kerusakan ekosistem dengan melakukan kegiatan konservasi maupun restorasi lingkungan. Kegiatan reboisasi yang secara sporadis kerap dilakukan oleh masyarakat maupun organisasi perlu ditekankan pada pemilihan spesies lokal (alami, asli) yang pernah ada atau masih tersisa di kawasan hutan tersebut untuk meminimalisir dampak daripada exotic invasive spesies yang dapat menurunkan tingkat keanekaragaman hayati di kawasan tersebut dan kepunahan spesies lokal.

\section{DAFTAR PUSTAKA}

[1] S. W. Adnyana, Erosi dan Pengunaan Lahan di Kawasan Bedugul, Prosiding Simposium Analisis Daya Dukung dan Daya Tapung Sumber Daya Air di Kawasan Tri-Danau Berata, Buyan dan Tamblingan Bali, 2005.

[2] Sutomo, Usada Bali dalam Perspektif Konservasi Kebun Raya "Eka Karya" Bali, Warta Kebun Raya, 2007.

[3] Anonim, Taru Premana, Dinas Kesehatan Prop. DATI I Bali, 1979.

[4] Anonim, Tanaman Obat dalam Lontar Usada, Dinas Kesehatan Prop. DATI I Bali, 1985.

[5] Anonim, IUCN Red List, IUCN The World Conservation Union, 1998.

[6] Anonim, Kawasan Konservasi di Pulau Bali, BKSDA Bali, 1999.

[7] Anonim, An Alphabetical List of Plant Species Cultivated in Bali Botanic Garden, UPT Balai Konservasi Tumbuhan Kebun Raya "Eka Karya" Bali-LIPI, 1999.

[8] C. A. Backer, R.C. B. van den Brink, Flora of Java, Vol. I. Leiden: The Rijksherbarium, 1963.

[9] K. Heyne, Tumbuhan Berguna Indonesia. Jilid I. Penerjemah Badan Litbang Kehutanan, Jakarta: Yayasan Sarana Wana Jaya, 1987.

[10] S. Mustaid $d k k$, Keanekaragaman Tumbuhan Usada dan Konservasi di Kebun Raya "Eka Karya” Bali, Prosiding Seminar Konservasi Tumbuhan Usada Bali dan Peranannya Dalam Mendukung Ekowisata, Kebun Raya Bali bekerja sama dengan Universitas Udayana dan Universitas Hindu Indinesia - Bali, 2007.

[11] N. Nala, Usada Bali, Upada Sastra Denpasar, Bali, 1996. 
Tabel 2. Jenis - jenis tanaman yang diperoleh selama eksplorasi

\begin{tabular}{|c|c|c|c|c|c|c|c|}
\hline No & Nama Tumbuhan & $\frac{\vec{z}}{\bar{n}}$ & 营 & 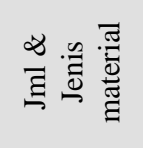 & 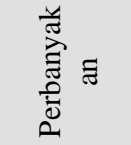 & Tempat dan lokasi & $\begin{array}{l}\text { Ket. Habitat, } \\
\text { Lintang/Bujur } \\
\text { Altitude, dll }\end{array}$ \\
\hline 1 & - & Elaeoc. & Pohon & 5 Stek & Biji, stek & $\begin{array}{l}\text { TWA Buyan- } \\
\text { Tamblingan }\end{array}$ & $\begin{array}{l}\text { Pinggir danau Buyan, } 1.190 \\
\text { mdpl } \\
\text { Kelerengan } 10^{\circ}\end{array}$ \\
\hline 2 & Hibiscus sp & Malvac. & Pohon & 5 Stek & Stek & $\begin{array}{l}\text { TWA Buyan- } \\
\text { Tamblingan }\end{array}$ & $\begin{array}{l}\text { Di pinggir hutan, } 1.150 \mathrm{~m} \\
\text { dpl } \\
\text { Kelerengan } 10^{\circ}\end{array}$ \\
\hline 3 & $\begin{array}{l}\text { Agathis dammara } \\
\text { (Lamb.)Rich. }\end{array}$ & Arau. & Pohon & 5 Stek & Stek, biji & $\begin{array}{l}\text { TWA Buyan- } \\
\text { Tamblingan }\end{array}$ & $\begin{array}{l}\text { Di pinggir hutan, } 1.200 \mathrm{~m} \\
\text { dpl } \\
\text { Kelerengan } 10^{\circ}\end{array}$ \\
\hline 4 & $\begin{array}{l}\text { Rauvolfia javanica Koord. } \\
\text { \& Valeton }\end{array}$ & Apoc. & Pohon & 5 Stek & Stek, biji & $\begin{array}{l}\text { TWA Buyan- } \\
\text { Tamblingan }\end{array}$ & $\begin{array}{l}\text { Di pinggir hutan, } 1.150 \mathrm{~m} \\
\text { dpl } \\
\text { Kelerengan } 10^{\circ}\end{array}$ \\
\hline 5 & - & Sterc. & Perdu & 1 Anakan & Biji, stek & $\begin{array}{l}\text { TWA Buyan- } \\
\text { Tamblingan }\end{array}$ & $\begin{array}{l}\text { Di dalam hutan, } 1.150 \mathrm{~m} \mathrm{dpl} \\
\text { Kelerengan } 20^{\circ}\end{array}$ \\
\hline 6 & - & Meliac. & $\begin{array}{l}\text { Pohon/ } \\
\text { perdu }\end{array}$ & 5 Anakan & Biji & $\begin{array}{l}\text { TWA Buyan- } \\
\text { Tamblingan }\end{array}$ & $\begin{array}{l}\text { Di pinggir jalan hutan, } 1.150 \\
\mathrm{~m} \mathrm{dpl} \\
\text { Kelerengan } 10^{\circ}\end{array}$ \\
\hline 7 & $\begin{array}{l}\text { Scheffleraelliptica } \\
\text { (Blume) Harms. }\end{array}$ & Aral. & $\begin{array}{l}\text { Perdu/ } \\
\text { Rambat }\end{array}$ & 5 Anakan & Biji & $\begin{array}{l}\text { TWA Buyan- } \\
\text { Tamblingan }\end{array}$ & $\begin{array}{l}\text { Pinggir danau Buyan, } 1.150 \\
\text { m dpl } \\
\text { Kelerengan } 10^{\circ}\end{array}$ \\
\hline 8 & Toona sureni Blume & Meliac. & Pohon & 5 Anakan & Biji & $\begin{array}{l}\text { TWA Buyan- } \\
\text { Tamblingan }\end{array}$ & $\begin{array}{l}\text { Di dalam hutan, } 1.150 \mathrm{~m} \mathrm{dpl} \\
\text { Kelerengan } 20^{\circ}\end{array}$ \\
\hline 9 & Malaxis sp. & Orch. & $\begin{array}{l}\text { Anggrek } \\
\text { Terrest. }\end{array}$ & 5 Anakan & Split & $\begin{array}{l}\text { TWA Buyan- } \\
\text { Tamblingan }\end{array}$ & $\begin{array}{l}\text { Di dalam hutan lantai hutan } \\
1.220 \mathrm{~m} \text { dpl. }\end{array}$ \\
\hline 10 & $\begin{array}{l}\text { ElaeocarpusgrandiflorusJ. } \\
\text { E. Smith. }\end{array}$ & Elaeoc. & Pohon & 5 Anakan & Biji & $\begin{array}{l}\text { TWA Buyan- } \\
\text { Tamblingan }\end{array}$ & $\begin{array}{l}\text { Pinggir barat Danau } \\
\text { Tamblingan, } \\
1.110 \text { mdpl. Kelerengan } 15^{\circ}\end{array}$ \\
\hline 11 & $\begin{array}{l}\text { Dysoxylumcaulostachyum } \\
\text { Miq. (1) }\end{array}$ & Meliac. & Pohon & 5 Stek & Biji, stek & $\begin{array}{l}\text { TWA Buyan- } \\
\text { Tamblingan }\end{array}$ & $\begin{array}{l}\text { Pinggir danau Buyan, } 1.150 \\
\mathrm{~m} \text { dpl } \\
\text { Kelerengan } 10^{\circ}\end{array}$ \\
\hline 12 & Eugenia polycephala Miq. & Myrt. & Pohon & 5 Stek & Biji, stek & Desa Lemukih Buleleng & $\begin{array}{l}\text { Pinggir kali, pinggir jalan, } \\
600 \text { mdpl. }\end{array}$ \\
\hline 13 & $\begin{array}{l}\text { Murraya paniculata } \mathrm{L} . \\
\text { Jacq. }\end{array}$ & Rut. & Pohon & 5 Stek & Biji, stek & Desa Sudaji Buleleng & $\begin{array}{l}\text { Pinggir sawah, } 320 \text { mdpl. } \\
\text { Kelerengan } 10^{\circ}\end{array}$ \\
\hline 14 & Wrightia riligiosa D.C. & Apoc & Pohon & 5 Stek & Stek & Desa Sudaji Buleleng & $\begin{array}{l}\text { Pinggir sawah, } 320 \text { mdpl. } \\
\text { Kelerengan } 10^{\circ}\end{array}$ \\
\hline 15 & $\begin{array}{l}\text { Dysoxylumcaulostachyum } \\
\text { Miq. (2) }\end{array}$ & Meliac. & Pohon & $\begin{array}{c}5 \\
\text { Tanaman }\end{array}$ & Biji, stek & Desa Sudaji Buleleng & Pekarangan rumah 320 mdpl. \\
\hline 16 & $\begin{array}{l}\text { Garciniadulcis(Roxb.) } \\
\text { Kurz. }\end{array}$ & Clusiac. & Pohon & 5 Anakan & Biji & Desa Sudaji Buleleng & Pekarangan rumah 320 mdpl. \\
\hline 17 & $\begin{array}{l}\text { Bulbophyllum } \\
\text { angustifolium (Blume) } \\
\text { Lindl. }\end{array}$ & Orch. & $\begin{array}{l}\text { Anggrek } \\
\text { epifit }\end{array}$ & $\begin{array}{c}1 \\
\text { Tanaman }\end{array}$ & Biji, split & $\begin{array}{l}\text { TWA Buyan- } \\
\text { Tamblingan }\end{array}$ & $\begin{array}{l}\text { Di dalam hutan, } 1.150 \mathrm{~m} \mathrm{dpl} \\
\text { Kelerengan } 20^{\circ}\end{array}$ \\
\hline 18 & $\begin{array}{l}\text { Pholydota carnea (Blume) } \\
\text { Lindl. }\end{array}$ & Orch. & $\begin{array}{l}\text { Anggrek } \\
\text { epifit }\end{array}$ & $\begin{array}{c}1 \\
\text { Tanaman }\end{array}$ & Splitting & $\begin{array}{l}\text { TWA Buyan- } \\
\text { Tamblingan }\end{array}$ & $\begin{array}{l}\text { Di dalam hutan Danau } \\
\text { Tamblingan } \\
1.150 \text { m dpl Kelerengan } 20^{\circ}\end{array}$ \\
\hline 19 & Alpinia galanga Wild. & Zing. & Rumpun & $\begin{array}{c}1 \\
\text { Tanaman }\end{array}$ & Umbi & $\begin{array}{l}\text { Desa Sari Mekar Kab. } \\
\text { Buleleng }\end{array}$ & $\begin{array}{l}\text { Di tegalan, } 100 \mathrm{~m} \mathrm{dpl} \\
\text { Kelerengan } 10^{\circ}\end{array}$ \\
\hline 20 & Vanda limbatta Blume & Orch. & $\begin{array}{l}\text { Anggrek } \\
\text { epifit }\end{array}$ & $\begin{array}{c}5 \\
\text { Tanaman }\end{array}$ & Splitting & $\begin{array}{l}\text { Desa Sari Mekar Kab. } \\
\text { Buleleng }\end{array}$ & $\begin{array}{l}\text { Di tegalan, } 100 \mathrm{~m} \mathrm{dpl} \\
\text { Kelerengan } 10^{\circ}\end{array}$ \\
\hline 21 & Dendrobium virardii & Orch. & $\begin{array}{l}\text { Anggrek } \\
\text { epifit }\end{array}$ & 5 Anakan & $\begin{array}{l}\text { Splitting, } \\
\text { anakan }\end{array}$ & $\begin{array}{l}\text { Desa Sari Mekar Kab. } \\
\text { Buleleng }\end{array}$ & $\begin{array}{l}\text { Di tegalan, } 100 \mathrm{~m} \mathrm{dpl} \\
\text { Kelerengan } 10^{\circ}\end{array}$ \\
\hline 22 & $\begin{array}{l}\text { Albizia falcataria (L.) } \\
\text { Fosberg. }\end{array}$ & Legum. & Pohon & 5 Stek & Stek & $\begin{array}{l}\text { TWA Buyan- } \\
\text { Tamblingan }\end{array}$ & $\begin{array}{l}\text { Di dalam hutan Danau Buyan } \\
1.150 \mathrm{~m} \text { dpl Kelerengan } 20^{\circ}\end{array}$ \\
\hline
\end{tabular}

Ket: Cetak tebal merujuk pada jenis yang menjadi target eksplorasi 